\title{
Studi Kepustakaan Siswa Hiperaktif Dalam Pembelajaran Di Sekolah
}

\author{
Yunia Dwi Puspitasari ${ }^{1}$, Wisda Miftakhul Ulum ${ }^{2}$ \\ Prodi Studi PGSD Universitas Bhinneka PGRI ${ }^{1,2}$ \\ Pyunia67@gmail.com¹, Wisda.miftakhul@gmail.com²
}

\begin{abstract}
Abstrak
Tujuan penelitian ini adalah Berdasarkan rumusan masalah di atas maka tujuan utama penulisan ini adalah "untuk meyusun cara penanganan siswa hiperaktif dalam pembelajan di sekolah berdasarkan studi pustaka Metode penelitian ini adalalah metode Studi Kepustakaan, jenis penelitian ini adalah Studi Kepustakaan (Library Research),sumber penelitian ini adalah buku, jurnal dan situs internet yang terkait dengan topik yang telah dipilih. Sumber data penelitian ini terdiri dari 10 jurnal tentang Studi kepustakaan penanganan siswa Hiperaktif dalam pembelajaran di sekolah . Teknik pengumpulan data dalam penelitian ini adalah dokumentasi, yaitu mencari data mengenai hal-hal atau variabel yang berupa catatan, buku, makalah atau artikel, jurnal intrumen dalam penelitian ini adalah daftar check-lis klasifikasi bahan penelitian, skema/peta penulisan dan format catatan penelitia. Teknik analisis data yang di pakai metode analisis isi (Content Analysis).Hasil Keseluruhan penelitian ini adalah ada beberapa ciri-ciri dan penanganan siswa hiperraktif yaitu Ada 70 ciri-ciri anak hiperaktif untuk anak tingkat kanakkanak dan sekolah dasar dan sekolah menengah atas. Kesimpulan adalah Ada 44 Cara penanganan anak hiperaktif untuk anak tingkat kanak-kanak,sekolah dasar dan sekolah menegah atas.
\end{abstract}

Kata Kunci: Penanganan,Siswa Hiperaktif,Pembelajara Sekolah 


\section{PENDAHULUAN}

Menurut Rochmad Mulyono (2003:4) Hiperaktif merupakan kelainan perilaku yang tidak jelas asal usulnya “ Tim ahli puspa Swara” (Jiang et al., 2018). Menurut Herawan dalam Zaviera(2008: 14), "Ditinjau secara psikologis, hiperaktif adalah gangguan tingkah laku yang tidak normal, disebabkan disfungsi neurologis dengan gejala utama tidak mampu memusatkan perhatian." (Hidayati, 2015). Menurut Lissauer \& Clayden menyatakan bahwa siswa hiperaktif itu adalah terjadinya disorganisasi afektif, penurunan kontrol diri dan aktivitas yang berlebihan secara nyata.(Sultan, 2015).

Guru memakai teknik mengajar yang bervarian sesuai pada tujuannya dan gayanya mengajar guru. Berdasarkan hasil observasi di kelas III pada tanggal 16 September 2019. Ditemukan permasalahan yakni 4 siswa dari kelas III tidak fokus pada pembelajaran sehingga banyak mata pelajaran yang tidak tersampaikan siswa tersebut yaitu E,W,F,dan A.

Secara implisit dalam pengertian ini terdapat kegiatan memilih, menetapkan, mengembangkan metode untuk mencapai hasil pembelajaran yang diinginkan.(Fakhrurrazi, 2018). Pola pembelajaran yang terjadi saat ini seringkali masih bersifat transmisif, yaitu siswa secara pasif menyerap struktur pengetahuan yang diberikan guru atau yang ada pada buku pelajaran saja (Pane \& Darwis Dasopang, 2017). Belajar dalam pandangan Islam memiliki arti yang sangat penting,sehingga hampir setiap saat manusia tak pernah lepas dari aktivitas belajar (Hermawan, 2017).

Trianto (2010:17) mengatakan "Pembelajaran merupakan aspek kegiatan manusia yang kompleks, yang tidak sepenuhnya dapat dijelaskan” (Mózo, 2017) . Berdasarkan penemuan penelitian hiperaktif serta pentingnya penelitian yang relevan serta pentingnya pembelajaran hiperaktif maka penelitian ini berjudul "Studi kepustakaan penangana siswa hiperaktif dalam pembalajaran di sekolah". Tujuan PenelitiaBerdasarkan rumusan masalah di atas maka tujuan utama penulisan ini adalah "untuk meyusun cara penanganan siswa hiperaktif dalam pembelajan di sekolah berdasarkan studi pustaka.

Kajian Pustaka Kajian menengani Studi Kpustakaan penanganan siswa hiperaktif dalam pembelajaran di sekolah di analisis sebagai berikut: Kajian Teori Siswa Hiperaktif Pengertian Hiperaktif Menurut Undang-Undang Sistem Pendidkan Nasional Nomer 20 Tahun 2003 (Latif, 2013:25) Pendidikan anak usia dini merupakan suatu upaya yang ditujukan bagi anak sejak lahir sampai dengan usia enam tahun yang dilakukan melalui pemberian rangsangan pendidikan untuk membantu pertumbuhan dan perkembangan jasmani dan rohani agar anak memiliki kesiapan dalam memasuki 
pendidikan lebih lanjut. Perilaku hiperaktif merupakan suatu sikap dimana dalam setiap aktifitas dilakukan secara berlebihan dan tidak mampu mengontrol perilaku dalam lingkungan yang ada(Setia Komala Sari). Arga Paternotte dan Jan Buitelaar (2010: 4) mengemukakan bahwa hiperaktif atau yang sering disebut dengan Attention Deficit Hyperactivity Disorder (ADHD) anak yang selalu bergerak sepanjang hari, dan tidak dapat duduk diam dikursi, merasa tidak tenang, mudah terganggu dan cepat frustrasi.

Jenis Hiperaktif Tidak Memusatkan Perhatian Pada kebanyakan kejadian nyata anak hiperaktif, anak Jenis hiperaktif pada anak ini tidak mengalami tanda jenis hiperaktif pada anak maupun berlebihan, akan tetapi akan sangat mudah terganggu perhatiannya dan biasanya jenis hiperaktif pada anak ini terdapat pada anak wanita dengan tanda yang bisa berupa selalu atau sering melamun dan merasa seolah sedang berada di awang awang. Tindakan Berlebihan Untuk jenis hiperaktif pada anak yang kedua ini, kebanyakan anaknya akan menunjukkan tanda jenis hiperaktif pada anak dan berlebihan secara umum, namun ia masih dapat berkonsentrasi dan masih dapat memusatkan perhatian pada hal hal yang dia inginkan. Gabungan Keduanya Pada jenis hiperaktif pada anak ketiga ini merupakan yang paling banyak ditemui pada anak anak zaman sekarang dan umumnya jenis hiperaktif pada anak inilah yang justru disebut dengan jenis hiperaktif pada anak Pada kebanyakan kejadian nyata anak hiperak

Dampak Positif Hiperaktif Kreativitas - Anak-anak yang ADD / ADHD dapat luar biasa kreatif dan imajinatif. Anak yang telah sepuluh lamunan dan pemikiran yang berbeda sekaligus bisa menjadi masalah master-solver, air mancur ide, atau seorang seniman inventif. Anak-anak dengan ADD dapat dengan mudah terganggu, tapi kadang-kadang mereka melihat apa yang orang lain tidak melihat. Fleksibilitas Karena anak-anak dengan ADD / ADHD mempertimbangkan banyak pilihan sekaligus, mereka tidak menjadi salah satu alternatif set pada awal dan lebih terbuka untuk ide-ide yang berbeda.

Antusiasme dan spontanitas - Anak-anak dengan ADD / ADHD jarang membosankan! Mereka tertarik pada banyak hal yang berbeda dan memiliki kepribadian yang hidup. Singkatnya, jika mereka tidak menjengkelkan Anda (dan kadang-kadang bahkan ketika mereka), mereka banyak menyenangkan dengan. Energi dan drive - Ketika anak-anak dengan ADD / ADHD termotivasi, mereka bekerja atau bermain keras dan berusaha untuk sukses. Ini sebenarnya mungkin sulit untuk mengalihkan perhatian mereka dari tugas yang menarik bagi mereka, terutama jika kegiatan ini adalah interaktif atau tangan-on.

Sebab-sebab Perilaku Hiperaktif Sebab-sebab hiperaktif ada 4 Menurut Flanagen ( 202 
: 3 ) yaitu : Faktor GenetiK/ Bawaan Kembar satu telur lebih memungkinkan hiperaktif dibanding kembar dua telur. Pada sistem syarafnya terdapat ketidakseimbangan neurokimia. Faktor Neurologik Penelitian menunjukan, anak hiperaktif lebih banyak disebabkan karena gangguan fungsi otak. Adanya brain damage akibat kesulitan pranatal atau perinatal, penyakit berat, cidera otak

Akibat Perilaku Hiperaktif Dianggap sebagai anak nakal oleh masyarakat sekitarnya mengalami gangguan dalam bidang akademik dan sosial cenderung sering melanggar peraturan Akan mengalami depresi dengan berbagai gangguan perilaku yang pada dasarnya merupakan upaya untuk mencari perhatian orang tua maupun guru. cara mengatasi Perilaku Hiperaktif Menurut Dr. Mary Go Setiawani (2000) upaya yang perlu dilakukan dalam menangani anak hiperaktif melalui: Penggunaan Obat Dokter umumnya menganjurkan penggunaan obat untuk menolong anak yang hiperaktif, dan hal itu pun sudah dibuktikan bermanfaat dalam menenangkan mereka. Jika masalahnya cukup serius dan penyebabnya bukan masalah emosi, maka penggunaan obat harus sesuai dengan petunjuk dokter dan jangan sampai ada efek sampingannya. Penting sekali untuk berkonsultasi dengan dokter ahli saraf.

Pengaturan Makanan Dalam konsultasi dengan dokter sebaiknya orangtua menanyakan apakah anaknya itu alergi terhadap satu macam makanan. Selain itu, perlu ada pengendalian terhadap makanan sebab ada banyak bukti terhadap kebenaran ini. Dalam keseharian pengaturan makanan dari orang tua juga sangat penting antara lain: Hindarkan Pemanjaan Anak jangan dimanjakan jika tahu bahwa penyebab hiperaktifnya karena masalah biologis.

Orangtua harus bertahan dengan peraturan yang telah diberikan dan menuntut anak agar menaatinya. Tunjukkan dengan mantap dan wibawa bahwa orangtua ingin ditaati oleh anakanaknya supaya pernyataan ini juga memberi rasa aman kepada anak. Sikap bertahan ini bukan berarti kejam, keras, diktator atau berhati baja, tetapi sebaliknya justru untuk membina dan mengajar anak tentang apa yang harus mereka lakukan.

Cara penangannya antara lain: Menciptakan Lingkungan yang Tenang Orang tua berupaya menciptakan suasana yang tenang di tempat anak itu biasa bergerak, misalnya: di kamar atau di ruang bermain. Bila lingkungan tempat tinggalnya sangat bising, sebaiknya pindah rumah agar anak itu dapat bertumbuh dalam situasi yang baik. Memilih Acara Televisi dengan Hati-hati Acara televisi yang menampilkan adegan kekerasan, lagu yang ribut dan sinar yang bergerak menyilaukan, dapat merangsang anak dan mengakibatkan mereka emosional.

Cegahlah anak untuk meniru adegan-adegan yang tidak baik. Oleh sebab itu, pilihlah 
acara televisi yang beradegan lembut dan baik. Gunakan Tenaga Ekstra dengan Tepat Anak hiperaktif biasanya kurang dapat mengendalikan diri. Namun, apabila sikap agresifnya dapat disalurkan dalam aktivitas yang tepat, sesungguhnya akan mengurangi keonaran.

Misalnya dengan mengizinkan dia mengikuti aktivitas di luar rumah atau membuat pekerjaan rumah bersama teman atau dalam proses belajar mengajar di kelas, sehingga dengan demikian ia dapat menyalurkan tenaga ekstranya dengan benar. Membimbing dalam Kebenaran meski anak hiperaktif sering tidak mampu menguasai diri dengan perilakunya, orangtua atau guru tidak seharusnya bersikap acuh dan menyerah. Setiap perilaku yang tidak dapat diterima harus dicegah, kemudian tentukan suatu standar yang sesuai dengan kebenaran.

Perlu ada kesabaran untuk mengajarkan hal ini, walaupun harus dilakukan secara berulang-ulang. Apabila orangtua tidak putus asa, anak akan mempunyai harapan untuk disembuhkan. Hal lain yang tidak boleh dilupakan adalah mengajak anak untuk berdoa kepada Tuhan dan bersandar pada pertolongan-Nya.

Ciri-ciri Perilaku Hiperaktif Tidak Fokus Misalnya, anak Anda hiperaktif. Maka, kebanyakan dari kegiatan yang sedang dia lakukan tidak bisa bertahan lama. Saat dia bermain bola, kemudian ada anak lain yang melintas di depan sambil membawa balon, dia akan membuang bolanya dan ikut bermain balon bersama anak lain.

Begitu ada anak lain yang berbeda, dia bisa mengalihkan perhatiannya untuk mengikuti anak tersebut. Anak hiperaktif tidak bisa bertahan diam lebih dari 5 menit. Anak ini juga suka berteriak-teriak tidak jelas, dan berbicara semaunya. Juga memiliki sikap yang tidak mudah dipahami.

Sifat Menentang Anak hiperaktif lebih sulit dinasehati dari pada anak non-hiperaktif. Misal, ia sedang bermain naik turun tangga dan kita memintanya untuk berhenti, ia akan diam saja atau marah dengan tetap melanjutkan bermain. Destruktif Sebagai perusak ulung, anak hiperaktif harus dijauhkan dari ruangan yang banyak benda-benda berharga atau barang pecah belah dan sejenisnya.

Sikap yang suka melempar, menghancurkan barang inilah yang disebut destruktif. Tidak Mengenal Lelah Tidak akan tampak kelelahan saat ia bermain maupun setelah ia bermain. Setiap hari berlari, berjalan dan melakukan kegiatan tanpa tujuan jelas, bergerak terus adanya. Tanpa Tujuan Jelas Anak aktif membuka buku untuk dibaca, anak hiperaktif membuka buku untuk disobek, dilipat-lipat, atau dibolak balik saja tanpa membaca. Bukan Penyabar yang Baik Dan Usil Sering saat bermain, ia dengan tidak sabar mengambil mainan dengan paksa. Tidak suka 
jika menunggu giliran bermain. Suka mendorong, mencubit, atau memukul tanpa

\section{METODE PENELITIAN}

jenis/pendekatan penelitian yang berupa Studi Kepustakaan (Library Research). Studi kepustakaan merupakan suatu studi yang digunakan dalam mengeumpulkan informasi dan data dengan bantuan berbagai macam material yang ada di perpustakaan seperti dokumen, buku, majalah, kisah-kisah sejarah, dsb (Mardalis:1999). Studi kepustakaan juga dapat mempelajari beberbagai buku referensi serta hasil penelitian sebelumnya yang sejenis yang berguna untuk mendapatkan landasan teori mengenai masalah yang akan diteliti (Sarwo)

Studi kepustakaan juga berarti teknik pengumpulan data dengan melakukan penelaahan terhadap buku, literatur, catatan, serta berbagai laporan yang berkaitan dengan masalah yang ingin dipecahkan (Nazir:1988). Sedangkan menurut ahli lain studi kepustakaan merupakan kajian teoritis, referensi serta literatur ilmiah lainnya yang berkaitan dengan budaya, nilai dan norma yang berkembang pada situasi sosial yang diteliti (Sugiyono:2012). Metode penelitian kepustakaan ini digunakan untuk menyusun konsep mengenai kepustakaan penanganan siswa Hiperaktif dalam pembelajaran di sekolah yang nantinya dapat digunakan sebagai pijakan dalam mengembangkan langkah-langkah praktis sebagai alternatif pendekatan konseling. Adapun langkah-langkah dalam penelitian kepustakaan menurut (Moleong,2006) adalah sebagai berikut :

Menyusun rancangan penelitian, Menyusun permasalahan yang dipilih yaitu kepercayaan diri siswa dan pola komunikasi keluarga jawa islam. Mengajukan judul penelitian kepada Dosen Pembimbing sekaligus Ketua Prodi PGSD STKIP PGRI Tulungagung. Menyusun proposal penelitian sesuai denga permasalahan dan judul penelitian yang dipilih.

Sumber data yang menjadi bahan akan penelitian ini berupa buku, jurnal dan situs internet yang terkait dengan topik yang telah dipilih. Sumber data penelitian ini terdiri dari 10 jurnal tentang Studi kepustakaan penanganan siswa Hiperaktif dalam pembelajaran di sekolah . Teknik pengumpulan data dalam penelitian ini adalah, dokumentasi, yaitu mencari data mengenai hal-hal atau variabel yang berupa catatan, buku, makalah atau artikel, jurnal.

Instrumen penelitian dalam penelitian ini adalah daftar check-lis klasifikasi bahan penelitian, skema/peta penulisan dan format catatan penelitia. Teknik analisis data yang digunakan dalam penelitian ini adalah metode analisis isi (ContenAnalysis). Analisis ini digunakan untuk mendapatkan inferensi yang valid dan dapat diteliti ulang berdasarkan 
konteksnya (Kripendoff, 1993) Dalam analisis ini akan dilakukan proses memilih, membandingkan,menggabungkan dan memilah berbagai pengertian hingga ditemukan yang relevan (Serbaguna, 2005).

Untuk menjaga kekelan proses pengkajian dan mencegah serta mengatasi mis informasi ( Kesalahan pengertian manusiawi yang bisa terjadi karena kekurangan penulis pustaka) maka dilakukan pengecekan antar pustaka dan memperhatikan komentar pembimbing (Sutanto, 2005)

\section{HASIL DAN PEMBAHASAN}

Ciri ciri Siswa Hiperaktif. Siswa sering sekali meluapkan emosinya dengan kasar kepada orangtuanya. Apabila sedang marah atau bosan kerap kali otangtua yang akan dihajar sebagai pelampiasan emosinya.

Anak hiperaktif biasanya menunjukkan suatu kondisi yang membuat ia tidak mampu mengendalikan perilakunya. Siswa-siswi saat disekolah sulit berkonsentrasi. Dan sulit bersosialisasi. Anak mereka biasa menggunakan gadget satu sampai dua jam bahkan lebih untuk bermain dan menonton video. Anak yang sulit dikendalikan. Sering menggerak-gerakkan tangan atau kaki ketika duduk, atau sering menggeliat. ering meninggalkanntempat duduknya, padahal seharusnya ia duduk manis.

Sering berlari-lari atau memanjat secara berlebihan pada keadaan yang tidak selayaknya. Sering tidak mampu melakukan atau mengikuti kegiatan dengan tenang. Selalu bergerak, seolaholah tubuhnya didorong oleh mesin. Juga, tenaganya tidak pernah habis.

Sering terlalu banyak bicara.Sering sulit menunggu giliran. Sering memotong atau menyela pembicaraan Jika diajak bicara tidak dapat memperhatikan lawan bicaranya (bersikap apatis terhadap lawan bicaranya). Anak juga suka berteriak-teriak tidak jelas.Kadang berlari naik keatas meja dan memanjat. Sulit bermain dengan permainan yang membutuhkan konsentrasi yang lama. Ciri - ciri Siswa Hiperaktif Tingkat Taman Kanak-kanak. Siswa-siswi saat disekolah sulit berkonsentrasi. Serta sulit bersosialisasi. Anak mereka biasa menggunakan gadget satu sampai dua jam bahkan lebih untuk bermain dan menonton video. Anak juga suka berteriakteriak tidak jelas. Kadang berlari naik keatas meja dan memanjat.

Ciri - ciri Siswa Hiperaktif Tingkat Sekolah Dasar. Siswa sering sekali meluapkan emosinya dengan kasar kepada orangtuanya. Apabila sedang marah atau bosan kerap kali otangtua yang akan dihajar sebagai pelampiasan emosinya. Anak hiperaktif biasanya 
menunjukkan suatu kondisi yang membuat ia tidak mampu mengendalikan perilakunya. Anak yang sulit dikendalika. Ciri - ciri Siswa Hiperaktif Tingkat Sekolah Atas. Sering menggerakgerakkan tangan atau kaki ketika duduk, atau sering menggeliat. Sering meninggalkan tempat duduknya, padahal seharusnya ia duduk manis. Sering berlari-lari atau memanjat secara berlebihan pada keadaan yang tidak selayaknya. Sering tidak mampu melakukan atau mengikuti kegiatan dengan tenang. Selalu bergerak, seolah-olah tubuhnya didorong oleh mesin. Juga, tenaganya tidak pernah habis.

Cara Penanganan Siswa Hiperaktif. Orangtua anak hiperaktif lebih terlibat dalam perkembangan sosialisasi dilingkungan keluarga juga sekolah Dan juga ikut aktif memantau lingkungan bermain siswa misalnya dengan menemani siswa bermain bersama teman-teman. Dan juga lebih sabar dan bijak dalam menghadapi tingkah laku dan emosinya

Memberikan batasan waktu untuk bermain gadget pada anak. Mengalihkan perhatian anak dengan dengan melakukan hal yang menarik seperti mengajak bermain anak bermain diluar rumah. Cara Penanganan Siswa Hiperaktif Tingkat Taman Kanak-kanak. Memberikan batasan waktu untuk bermain gadget pada anak. Mengalihkan perhatian anak dengan dengan melakukan hal yang menarik seperti mengajak bermain anak bermain diluar rumah. Ajak anak untuk lebih banyak beraktivitas (olahraga, bermain musik, dll). serta bersosialisasi dengan teman sebayanya.

Orangtua anak hiperaktif lebih terlibat dalam perkembangan sosialisasi dilingkungan keluarga juga sekolah. Dan juga ikut aktif memantau lingkungan bermain siswa misalnya dengan menemani siswa bermain bersama teman-teman. Dan juga lebih sabar dan bijak dalam menghadapi tingkah laku dan emosinya, membujuk anaknya untuk mau mendengarkan. Cara Penanganan Siswa Hiperaktif Tingkat Sekolah Menengah atas.

Dengan cara melakukan bimbingan konseling. Datang tepat waktu ketika melaksanakan ibadah shalat. Mematuhi peraturan yang sudah dibuat dalam melaksanakan ibadah shalat dan mengikuti kegiatan sesuai jadwal, agar dapat disiplin di butuhkan pembagian jadwal sehingga anak hiperaktif di latih untuk bisa mengikuti sesuai jadwal yang sudah ditentukan.

\section{SIMPULAN}

Ada 70 ciri-ciri anak hiperaktif untuk anak tingkat kanak-kanak dan sekolah dasar dan sekolah menengah atas. Tidak ada perbedaaan ciri-ciri hiperaktif untuk anak tingkat Taman kanakkanak, sekolah dasar dan sekolah menengah atas. Ada 44 Cara penanganan anak hiperaktif 
untuk anak tingkat kanak-kanak, sekolah dasar dan sekolah menegah atas. Tidak ada perbedaan cara penenganan hiperaktif untuk anak tingkat Taman kanak-kakanak,sekolah dasar dan sekolah menegah atas.

\section{DAFTAR PUSTAKA}

Alam, Fi. (2014). Fiptar Abdi Alam (2014). Pengaruh Layanan Bimbingan Dan Komseling Terhadap Siswa Yang Hiperaktif Di Sma Negeri 1 Tenetariaja, 1, 1-9

Citra Dirna, F. (2012). Meningkatkan Ketahanan Duduk Siswa Hiperaktif Melalui Media Mozaik. Jurnal Ilmiah Pendidikan Khusus, 1(September), 320-331.

Fatimah. (2012). PENANGANAN ANAK HIPERAKTIF MELALUI TERAPI BERMAIN (Studi Kasus di TK Al-Hidayah V Ngasinan Kwarasan Kecamatan Grogol Kabupaten Sukoharjo Tahun Ajaran 2011/2012). Naskah Publikas

Kelas, D. I., Slb, P., Redha, F. A. N., \& Putri, N. I. (2015). E-JUPEKhu EJUPEKhu. 4(September), 278-286.

Lisa, W., Kintan, M., Andhini, F., \& Risha, W. (2015). Kesabaran Ibu Bekerja Dalam Mengasuh Anak Hiperaktif Di Sdn Putraco-Indah. Psympathic, 2(2), 169-174

Nurhafizah. (2017). PEDAGOGI: Jurnal Anak Usia Dini dan Pendidikan Anak Usia Dini. Pedagogi, 3(3a), 72-77.

Oscar Hernan Lopez, \& Johana del Rosario Rangel. (2017).

Putri, D. B. (2019). Penanganan Anak Hiperaktif Melalui Permainan Puzzle Di Tk Desa Sraten 01 Tahun Ajaran 2018/2019

Raehang. (2014). Pembelajaran Aktif Sebagai Induk Pembelajaran Kooperatif. Jurnal Al-Ta'dib, 7(1), 149-167. Retrieved from ejournal.iainkendari.ac.id/al tadib/article/view/249/239 Rafidah, S. (2016).

Rozie, F., Haryani, W., \& Safitri, D. (2019). Peran Guru Dalam Penanganan Perilaku Anak Hiperaktif Di TK Negeri 1 Samarinda. JECE (Journal of Early Childhood Education), $1(2), 53-59$.

Hidayati, R. (2015). Peran Konselor Sekolah Dalam Meningkatkan Konsentrasi Pada Siswa Hiperaktif (Adhd). Refleksi Edukatika, 5(1). https://doi.org/10.24176/re.v5i1.431

Pendidikan, J., Pendidikan, G., Usia, A., Volume, D., \& Tahun, N. (2018). Jurusan Pendidikan Guru Pendidikan Anak Usia Dini Jurusan Pendidikan Guru Sekolah Dasar Fakultas Ilmu Pendidikan Universitas Pendidikan Ganesha e-Journal Pendidikan Anak Usia Dini Universitas Pendidikan Ganesha Jurusan Pendidikan Guru Pendidikan Anak Usia. 6(1), 43-53. 
Sultan, S. (2015). Perilaku Hiperaktif Siswa Di Smp Negeri 2 Pinrang. Al-Ishlah, 13(2), 130142. https://doi.org/10.35905/alishlah.v13i2.497

Telles, S., Reddy, S. K., \& Nagendra, H. R. (2019). 済無No Title No Title. Journal of Chemical Information and Modeling, 53(9), 1689-1699. https://doi.org/10.1017/CBO9781107415324.004 